\title{
Recovery of Bacillus licheniformis Alkaline Protease from Supernatant of Fermented Wastewater Sludge Using Ultrafiltration and Its Characterization
}

\author{
Jyothi Bezawada, ${ }^{1}$ S. Yan, ${ }^{1}$ Rojan P. John, ${ }^{1}$ R. D. Tyagi, ${ }^{1}$ and R. Y. Surampalli ${ }^{2}$ \\ ${ }^{1}$ INRS-ETE, Université du Québec, 490, Rue de la Couronne, QC, Canada G1K 9A9 \\ ${ }^{2}$ USEPA, P.O. Box-17-2141, Kansas City, Kansas, KS 66117, USA
}

Correspondence should be addressed to R. D. Tyagi, tyagi@ete.inrs.ca

Received 13 February 2011; Revised 30 April 2011; Accepted 3 May 2011

Academic Editor: Manuel Canovas

Copyright ( $) 2011$ Jyothi Bezawada et al. This is an open access article distributed under the Creative Commons Attribution License, which permits unrestricted use, distribution, and reproduction in any medium, provided the original work is properly cited.

\begin{abstract}
Investigation on recovery of alkaline protease from B. licheniformis ATCC 21424 fermented wastewater sludge was carried out by centrifugation and ultrafiltration. Optimization of ultrafiltration parameters (transmembrane pressure (TMP) and feed flux) was carried out with $10 \mathrm{kDa}$ membrane. TMP of $90 \mathrm{kPa}$ and feed flux of $714 \mathrm{~L} / \mathrm{h} / \mathrm{m}^{2}$ gave highest recovery (83\%) of the enzyme from the centrifuged supernatant. The recovered enzyme had given maximum activity at temperature of $60^{\circ} \mathrm{C}$ and at pH 10 . It was stable between $\mathrm{pH} 8$ to 10 and retained $97 \%$ activity at $60^{\circ} \mathrm{C}$ after $180 \mathrm{~min}$ of incubation. Enzyme activity was significantly augmented by metal ions like $\mathrm{Ca}^{2+}$ and $\mathrm{Mn}^{2+}$. Protease inhibitors like phenylmethyl sulphonyl fluoride (PMSF) and diisopropyl fluorophosphates (DFPs) completely inhibited the enzyme activity. The partially purified protease showed excellent stability and compatibility with various commercial detergents. The detergent (Sunlight) removed the blood stains effectively along with the enzyme as additive.
\end{abstract}

\section{Introduction}

The membrane separation processes are the most widespread in the field of biotechnology, and they are more easily operated and scaled up in comparison to other bioseparation processes such as chromatography, and electrophoresis. Among the various membrane separation processes, ultrafiltration is one of the processes that functions under pressure gradient which is mostly used for separation and purification of products including enzymes and other proteins [1-3] or to recover microbial products (cells and spores) present in a culture medium [4-6]. Because of the low amount of enzyme present in the cell-free filtrate, the water removal is a primary objective. Ultrafiltration is an effective technique that has been largely used for the recovery of enzymes $[7,8]$ and, in general, is a preferred alternative to evaporation. This pressure driven separation process is not expensive and also gives encouraging results with little loss of enzyme activity. This process offers both concentration and purification [9].
However, the application of membrane processes in general have some specific problems like fouling or membrane clogging due to the precipitates formed by the final product and/or deposition of solid particles on the membrane. If the solute flow towards the membrane is greater than the solute passing through the membrane, the solute accumulates on the surface of the membrane, this accumulation forms a concentration layer which is known as concentration polarization [10]. Tangential flow filtration is powerful and advantageous alternative over normal flow filtration as tangential flow filtration will significantly reduce the fouling of the membrane. The clogging or fouling can usually be alleviated or overcome by treatment with detergents, proteases, acids or alkalis [11]. In fact, the ultrafiltration process has been effectively in use for the recovery of organic compounds from several synthetic media [12-14].

Proteases are commercially important industrial enzymes accounting $60 \%$ of the total enzyme sales with two thirds of the proteases produced are from microorganisms 
[15-17]. Microbial enzymes are replacing chemical catalysts in manufacturing chemicals, food, leather goods, pharmaceuticals, and textiles. Among proteases, alkaline proteases are employed mainly as detergent additives because of their distinctive abilities to assimilate proteinaceous stains such as blood, chocolate, and milk. Currently, alkaline proteasebased detergents are preferred over the conventional synthetic detergents, as they have better cleaning properties, higher efficiency at lower washing temperatures, and safer dirt removal conditions [18]. Preferably, proteases used in detergent formulation must have a high activity level and stability over a wide range of $\mathrm{pH}$ and temperature. One of the major drawbacks affecting the stability of enzymes recovered from thermophiles at alkaline $\mathrm{pH}$ is that enzymes from alkalophiles confer stability over wide $\mathrm{pH}$ range but are generally thermolabile. So, there is always a need for proteases with all desirable properties to become accustomed with application conditions, and also, it is necessary to check the stability of the enzyme at elevated temperatures and $\mathrm{pH}$. Applications, such as protease for detergent industries need concentrated and cleaned enzyme to amend with detergent to get good performance during storage and application as well. The enzyme is cleaner when the medium is simple and defined, where, as in case of sludge medium, fermented enzyme contains many other sludge particles and other impurities, so enzyme has to be clarified and concentrated to get higher activity.

Huge amount of municipal wastewater sludge has been generating in Canada. Due to increase in population and other developments sludge management is becoming a crucial environmental concern due to strict regulations on sludge disposal. So, bioconversion of wastewater sludge into value added products is economic and ecofriendly approach. The use of wastewater sludge for the production of alkaline protease with Bacillus licheniformis has been successfully achieved in our laboratory $[19,20]$.

The aim of the present study was to recover and concentrate the alkaline protease activity from culture filtrate of fermented wastewater sludge using ultrafiltration technique. The efficiency of enzyme was examined in the presence of standard commercial detergents and the enzyme was characterized with respect to the effect of various additives such as stabilizers and inhibitors on the stability at higher temperatures and in alkaline $\mathrm{pH}$.

\section{Materials and Methods}

2.1. Bacterial Strain. Bacillus licheniformis strain ATCC 21424 was used in this study. An active culture was maintained by inoculating on nutrient agar (composition: $0.3 \%$ beef extract, $0.5 \%$ peptone, and $2 \%$ agar) plates and incubating at $35^{\circ} \mathrm{C}$ for $48 \mathrm{~h}$. The plates were stored at $4{ }^{\circ} \mathrm{C}$ for later use.

2.2. Sludge Samples and Composition. The wastewater secondary sludge samples collected from municipal wastewater treatment of Communauté Urbaine de Quebec (CUQ, Quebec) were used. The experiments were conducted at a sludge
TABLe 1: Physical and chemical characteristics of secondary sludge.

\begin{tabular}{|c|c|}
\hline Characteristics & Concentration \\
\hline \multicolumn{2}{|l|}{ Physical characteristics: } \\
\hline Total solids $(\mathrm{g} / \mathrm{L})$ & $29 \pm 1.2$ \\
\hline Volatile solids (g/L) & $18 \pm 0.6$ \\
\hline Suspended solids (g/L) & $22 \pm 0.9$ \\
\hline Volatile suspended solids (g/L) & $17 \pm 0.7$ \\
\hline $\mathrm{pH}$ & $5.7 \pm 0.3$ \\
\hline \multicolumn{2}{|l|}{ Chemical characteristics: } \\
\hline Total carbon (\%, dry total solids) & $38.12 \pm 1.5$ \\
\hline Total nitrogen (\%, dry total solids) & $5.5 \pm 0.3$ \\
\hline Ammonical nitrogen (mg N/kg) & $680 \pm 22.1$ \\
\hline Total phosphorus (mg P/kg) & $12422 \pm 42$ \\
\hline Orthophosphates (mg P/kg) & $7780 \pm 24$ \\
\hline \multicolumn{2}{|l|}{ Metals (in $\mathrm{mg} / \mathrm{kg}$ ) (dry basis): } \\
\hline $\mathrm{Al}^{3+}$ & $13305 \pm 41$ \\
\hline $\mathrm{Ca}^{2+}$ & $16160 \pm 45$ \\
\hline $\mathrm{Cd}^{2+}$ & $3.5 \pm 0.16$ \\
\hline $\mathrm{Cr}^{3+}$ & $66.5 \pm 2$ \\
\hline $\mathrm{Cu}^{2+}$ & $270 \pm 9$ \\
\hline $\mathrm{Fe}^{2+}$ & $10365 \pm 30$ \\
\hline $\mathrm{Mg}^{2+}$ & $1874 \pm 62$ \\
\hline $\mathrm{Mn}^{2+}$ & $198 \pm 6.9$ \\
\hline $\mathrm{K}^{+}$ & $1720 \pm 53$ \\
\hline $\mathrm{Pb}^{2+}$ & $61 \pm 2$ \\
\hline $\mathrm{Zn}^{2+}$ & $477 \pm 15$ \\
\hline
\end{tabular}

suspended solids concentration of $30 \mathrm{~g} / \mathrm{L}$. The sludge was centrifuged in order to obtain higher suspended solids concentration $(30 \mathrm{~g} / \mathrm{L})$. The sludge characteristics were measured according to standard methods [21] and sludge composition was presented in Table 1.

2.3. Inoculum and Cultural Conditions. A loopful of bacterial growth from a nutrient agar plate was used to inoculate a $500 \mathrm{~mL}$ Erlenmeyer flask containing $100 \mathrm{~mL}$ of sterilized nutrient broth (composition: $0.3 \%$ beef extract and $0.5 \%$ peptone) (sterilized at $121^{\circ} \mathrm{C}$ for $15 \mathrm{~min}$ ). The flask was incubated in a shaker incubator (New Brunswick) at $35^{\circ} \mathrm{C}$ with $220 \mathrm{rpm}$ for $12 \mathrm{~h} .500 \mathrm{~mL}$ Erlenmeyer flasks containing $100 \mathrm{~mL}$ of sterilized sludge were then inoculated with $2 \%$ $(\mathrm{v} / \mathrm{v})$ inoculum from the above flask. The flasks were incubated in the same way for $12 \mathrm{~h}$ and these actively growing cells were used as inoculum for fermentor experiments.

2.4. Fermentation. A fermenter (Biogénie Inc., Quebec) of $15 \mathrm{~L}$ capacity equipped with accessories and automatic control systems for dissolved oxygen, $\mathrm{pH}$, antifoam, impeller speed, aeration rate and temperature and with working volume of $10 \mathrm{~L}$ sludge supplemented with $1.5 \%(\mathrm{w} / \mathrm{v})$ soybean meal and $1.5 \%(\mathrm{w} / \mathrm{v})$ lactose (sterilized at $121^{\circ} \mathrm{C}$ for $30 \mathrm{~min}$ ) was used for production of extracellular alkaline protease. The medium was inoculated with $4.5 \%(\mathrm{v} / \mathrm{v})$ inoculum. Temperature and $\mathrm{pH}$ of the fermentation medium were 
controlled at $35^{\circ} \mathrm{C}$ and 7.5 , respectively. Dissolved oxygen concentration was maintained above $20 \%\left(1.56 \mathrm{mg} \mathrm{O}_{2} / \mathrm{L}\right)$ saturation (critical oxygen concentration) by agitating the medium initially at a speed of $200 \mathrm{rpm}$ and finally increased up to $500 \mathrm{rpm}$ and air flow rate was controlled automatically using a computer controlled system. The fermented broth was collected aseptically in HDPE bottles (VWR Canlab, Canada) after $42 \mathrm{~h}$ of fermentation and sealed with paraffin and preserved at $4^{\circ} \mathrm{C}$ for further use.

\subsection{Techniques for Recovery of Alkaline Protease from the Fermented Broths}

2.5.1. Centrifugation. Fermented broth was centrifuged at $9000 \mathrm{xg}$ for $30 \mathrm{~min}$ according to the procedure of Brar et al. [22]. The supernatant after the centrifugation of the fermented broths were collected and stored at $4^{\circ} \mathrm{C}$.

\subsubsection{Ultrafiltration}

Operating Principle and Washing of the Filter. The equipment used for ultrafiltration was of tangential flow filtration type (PREP/SCALE-TFF, Cartridges Millipore) with recirculation. The fluid was tangentially pumped along the surface of the membrane. Pressure was applied to force a portion of the fluid through the membrane to the permeate side. The supernatant from centrifuge was fed into the ultrafiltration equipment by a pump (Casy Load, Master Flex, Millipore). The supernatant was brought to room temperature $\left(25^{\circ} \mathrm{C}\right)$ in order to conduct ultrafiltration study. The process consisted of feeding aseptically a volume $(1 \mathrm{~L})$ of the supernatant from the centrifugation step referred to as "feed" through the membrane in order to concentrate the active components to a concentrated volume referred to as "retentate" which was $18 \%$ of the volume of the supernatant [28]. The flow of the supernatant was obtained by means of a pump whose flow varied between $45.5 \mathrm{~L} / \mathrm{h}$ and $250 \mathrm{~L} / \mathrm{h}$, which gave a flow of feed through the membrane ranging between $455 \mathrm{~L} / \mathrm{h} \mathrm{m}^{2}$ and $2500 \mathrm{~L} / \mathrm{h} / \mathrm{m}^{2}$. As for the flow of permeate, it generally depended on the TMP and the resistance of the membrane. After ultrafiltration, the permeate and retentate were collected in flasks. Sampling of the supernatant, retentate, and permeate was carried out for measurements of physical and biological parameters (total solids, suspended solids, soluble protein, and protease activity).

After each ultrafiltration operation, liquid in the membrane was completely drained. Taking into account the type of medium used in this study (biological environment), it was recommended to use an alkaline solution $(0.1 \mathrm{~N} \mathrm{NaOH})$. The alkaline solution was passed through the membrane until the membrane was clean. Later, the membrane was removed and inverted to facilitate complete washing. Resistance of the membrane can be determined by "normalized permeability weight" (NWP) as performance of the membrane depends on NWP. The NWP can be calculated by (1). In fact, during the use of the membrane, the value of NWP decreased, and when the value lies between $10 \%$ and $20 \%$ of its initial value (that of the new membrane, NWP of new membrane should be considered as $100 \%$ ), the membrane should then be changed [6]. Prior to ultrafiltration runs, we have determined the NWP to check the resistance of the membrane.

$$
\mathrm{NWP}=\frac{\text { water filtrate flux }}{\mathrm{TMP}(\text { Transmembrane pressure }(15 \mathrm{Psi})) \times \mathrm{TCF}_{20^{\circ} \mathrm{C}}(\text { temperature correction factor })}
$$

Membrane Size. Membranes with molecular weight cut-off (MWCO) of $10 \mathrm{kDa}$ and $100 \mathrm{kDa}$ were used in the present study (Millipore, prep/scale spiral wound TFF-1). The membrane was made up of regenerated cellulose and was of the type spiral wound TFF-1 module PLCC with a surface area of $0.1 \mathrm{~m}^{2}$. Supernatant was passed first through $100 \mathrm{kDa}$ membrane to eliminate all other sludge impurities and final permeate was collected as enzyme source to carry out optimization studies using membrane of $10 \mathrm{kDa}$. Concentrated enzyme was used for characterization purpose. Characteristics of the membranes were presented in Table 2.

Optimization of Parameters of Ultrafiltration. Transmembrane pressure and flux of the feed are important parameters to be controlled in ultrafiltration. For the optimization, the experiment was carried out for various values of TMP (70$110 \mathrm{kPa}$ ) and feed fluxes $\left(455-2500 \mathrm{~L} / \mathrm{h} / \mathrm{m}^{2}\right)$. In a typical ultrafiltration process, lower permeate flow results in higher solute concentration in the retentate. Samples were withdrawn to determine the suspended solids, total solids, soluble protein, and protease activity in the retentate and permeate.

\subsection{Analysis of Parameters}

2.6.1. Physical Parameters. The total solids of the samples (supernatant, retentate, and permeate) were measured by drying $30 \mathrm{~mL}$ volume at $105^{\circ} \mathrm{C}$ [21]. The suspended solids were determined by filtration through the $0.45 \mu \mathrm{m}$ membrane (Glass Microfiber Filter 934-AH of $42.5 \mathrm{~mm}$, Whatman) followed by drying at $105^{\circ} \mathrm{C}$. The determination of the soluble protein concentration of the samples (supernatant, retentate and permeate) was carried out using Braford method [23] with a spectroscopic measurement of the absorbance at $595 \mathrm{~nm}$. All the experiments were conducted in triplicates and the mean value was presented.

2.6.2. Alkaline Protease Activity. The modified method of Kunitz [24] was used to determine Protease activity. Fermented samples were centrifuged and the supernatant was collected as the crude enzyme source. The supernatant thus obtained was properly diluted with borate buffer ( $\mathrm{pH}$ 8.2). Protease activity was assayed by incubating $1 \mathrm{~mL}$ of properly diluted enzyme solution with $5 \mathrm{~mL}$ of casein $(1.2 \% \mathrm{w} / \mathrm{v}$, 
TABLE 2: Characteristics of the membrane.

\begin{tabular}{ll}
\hline Description of membrane & $\begin{array}{l}\text { Characteristics } \\
\text { of membrane }\end{array}$ \\
\hline Type & $\begin{array}{l}\text { Prep/scale spiral wound } \\
\text { TFF-1 }\end{array}$ \\
Filter type & Ultrafiltration \\
Length, cm (in.) & $23.4(9.2)$ \\
Diameter, cm (in.) & $5.8(2.3)$ \\
Minimum working volume $(\mathrm{mL})$ & 150 \\
pH range & $2.0-13.0$ \\
Configuration & Spiral wound cartridge \\
Filtration area (m $\left.{ }^{2}\right)$ & 0.23 \\
Operation temperature $\left({ }^{\circ} \mathrm{C}\right)$ & $4-50$ \\
$\begin{array}{l}\text { Filter material } \\
\text { Maximum Intel pressure, bar } \\
\text { (psi) }\end{array}$ & Regenerated cellulose \\
Recirculation rate $(\mathrm{L} / \mathrm{min})$ & $0-5.5(0-80)$ \\
$\begin{array}{l}\text { Molecular weight cut off } \\
(\mathrm{MWCO}), \mathrm{kDa}\end{array}$ & $1.0-6.0$ \\
\hline
\end{tabular}

Sigma-Aldrich Canada Inc) for $10 \mathrm{~min}$ at $37^{\circ} \mathrm{C}$ in a constant temperature water bath. The reaction was terminated by adding $5 \mathrm{~mL}$ of $10 \%(\mathrm{w} / \mathrm{v})$ trichloroacetic acid. This mixture was incubated for $30 \mathrm{~min}$ in order to precipitate the total nonhydrolyzed casein. Samples and blanks were filtered using Whatman filter paper (934-AH) after the incubation period. The absorbance of the filtrate was measured at $275 \mathrm{~nm}$. The validation of the results was established by treating a standard enzyme solution under identical experimental settings where activity was known. One international protease activity unit (IU) was defined as the amount of enzyme preparation required to liberate $1 \mu \mathrm{mol}(181 \mu \mathrm{g})$ of tyrosine from casein per minute at $\mathrm{pH} 8.2$ and $37^{\circ} \mathrm{C}$. All experiments were conducted in triplicate and the mean value was presented.

\subsection{Characterization of Partially Purified Enzyme}

2.7.1. Effect of $p H$ on Enzyme Activity and Stability of Protease. The activity of protease was measured at different $\mathrm{pH}$ values in the absence and presence of $10 \mathrm{~mm} \mathrm{CaCl}_{2}$. The $\mathrm{pH}$ was adjusted using different buffers; acetate buffer ( $\mathrm{pH} 5)$, phosphate buffer ( $\mathrm{pH}$ 6-7), borate buffer ( $\mathrm{pH} 8-9)$, bicarbonate buffer ( $\mathrm{pH} 10)$, and Robinson and stokes buffer ( $\mathrm{pH} 11-12$ ). Reaction mixtures were incubated at $37^{\circ} \mathrm{C}$ and the activity of the enzyme was measured.

Stability of the enzyme was determined by incubating the reaction mixtures at various $\mathrm{pH}$ values using different relevant buffers ( $\mathrm{pH} 5-12$ ) for $2 \mathrm{~h}$ at $37^{\circ} \mathrm{C}$. The residual activity after incubation was determined under standard assay conditions. Residual activities are obtained at respective $\mathrm{pH}$ values assuming the activity of enzyme before the incubation is $100 \%$.
2.7.2. Effect of Temperature on Activity and Stability of Protease. Optimum temperature was determined by activity assay on casein at $\mathrm{pH} 10$ from $30^{\circ} \mathrm{C}-90^{\circ} \mathrm{C}$ in the absence and presence of $10 \mathrm{~mm} \mathrm{CaCl}_{2}$ and relative protease activities were assayed at standard assay conditions using casein as substrate.

The thermostability of enzyme was measured by incubating the enzyme preparation at different temperatures ranging from $30^{\circ} \mathrm{C}-90^{\circ} \mathrm{C}$ for $180 \mathrm{~min}$ in the absence and presence of $10 \mathrm{~mm} \mathrm{CaCl}_{2}$. The residual activity after incubation was determined under the standard assay conditions. Residual activities are obtained at respective temperatures assuming the activity of the enzyme before the incubation is $100 \%$.

2.7.3. Effect of Enzyme Inhibitor and Chelator on Protease Activity. The effect of various protease inhibitors $(5 \mathrm{~mm})$ such as serine inhibitors (phenylmethyl sulphonyl fluoride [PMSF] and diisopropyl fluorophosphate [DFP]), cysteineinhibitors ( $\mathrm{p}$-chloromercuric benzoate $[p \mathrm{CMB}]$ and $\beta$-mercaptoethanol $[\beta-\mathrm{ME}]$, iodoacetate), dithiothreitol, and a chelator of divalent cations (ethylene diamine tetra acetic acid [EDTA]) on enzyme activity were investigated by preincubation with the enzyme solution for $30 \mathrm{~min}$ at $60^{\circ} \mathrm{C}$. The relative protease activity was measured under assay conditions.

2.7.4. Effect of Various Metal Ions on Enzyme Activity. To study the effect of various metal ions $\left(\mathrm{Ca}^{2+}, \mathrm{K}^{+}, \mathrm{Fe}^{2+}, \mathrm{Zn}^{2+}\right.$, $\mathrm{Hg}^{2+}, \mathrm{Mg}^{2+}, \mathrm{Mn}^{2+}, \mathrm{Cu}^{2+}, \mathrm{Co}^{2+}, \mathrm{Na}^{+}$) on enzyme activity, metal salt solutions were prepared in a concentration of $10 \mathrm{~mm}$ and $1 \mathrm{~mL}$ of metal solution was mixed with $5 \mathrm{~mL}$ of enzyme and was incubated for $2 \mathrm{~h}$. Enzyme activities were measured at standard assay conditions. The activity is expressed in terms of relative activity assuming that the activity of the enzyme in the absence of metal salts just before the initiation of the treatment is $100 \%$.

2.7.5. Hydrolysis of Protein Substrates. The effect of various protein substrates such as casein, BSA, egg albumin, and gelatin were determined under assay conditions by mixing $1 \mathrm{~mL}$ of the enzyme and $5 \mathrm{~mL}$ of assay buffer containing the protein substrates $(1.2 \% \mathrm{w} / \mathrm{v})$. After incubation at $60^{\circ} \mathrm{C}$ for $10 \mathrm{~min}$, the reaction was stopped by adding $10 \%$ TCA (w/v). The undigested protein was removed by filtration (whatman filter paper, 934-AH) and the absorbance of the filtrate was measured at $275 \mathrm{~nm}$. The protease activity towards casein was taken as a control.

2.7.6. Effect of Detergents on Stability of Protease Activity. Protease enzyme stability with commercial detergents was studied in the presence of $10 \mathrm{~mm} \mathrm{CaCl}_{2}$. The detergents used were Merit Selection (Metrobrands, Montreal, Quebec), La Parisienne (Lavo Inc., Montreal, Quebec), Arctic Power (Phoenix brands Canada), Bio-vert (Savons Prolav Inc., Canada) and Sunlight (the Sun products of Canada corporation, Ontario). The detergent solutions $(0.7 \% \mathrm{w} / \mathrm{v})$ were prepared in distilled water and incubated with the partially purified enzyme $(2 \mathrm{~mL}$ recovered enzyme and $1 \mathrm{~mL}$ detergent of $0.7 \%$ ) up to $3 \mathrm{~h}$ at $60^{\circ} \mathrm{C}$. At every $30 \mathrm{~min}$ interval, the protease activity was estimated under standard 
TABLE 3: Maximum values of protease activity, soluble protein, total solids, and suspended solids at optimum TMP and feed flux.

\begin{tabular}{lccc}
\hline Parameters & Supernatant & \multicolumn{2}{c}{ Retentate } \\
& Before UF & TMP $(90 \mathrm{kPa})$ & Feed flux $\left(714 \mathrm{~L} / \mathrm{h} / \mathrm{m}^{2}\right)$ \\
\hline Protease $(\mathrm{IU} / \mathrm{mL})$ & $15 \pm 0.72$ & $69 \pm 3.4$ & $67.3 \pm 3.3$ \\
Soluble protein $(\mathrm{mg} / \mathrm{mL})$ & $1.7 \pm 0.08$ & $7.8 \pm 0.39$ & $7.6 \pm 0.37$ \\
Total solids $(\mathrm{g} / \mathrm{L})$ & $12 \pm 0.6$ & $55.2 \pm 2.75(9.9 \mathrm{~g} / 180 \mathrm{~mL}$ & $54 \pm 2.7(9.72 \mathrm{~g} / 180 \mathrm{~mL})$ \\
Suspended solids $(\mathrm{g} / \mathrm{L})$ & $0.6 \pm 0.03$ & $2.7 \pm 0.13(0.48 \mathrm{~g} / 180 \mathrm{~mL})$ & $2.52 \pm 0.12(0.45 \mathrm{~g} / 180 \mathrm{~mL}$ \\
\hline
\end{tabular}

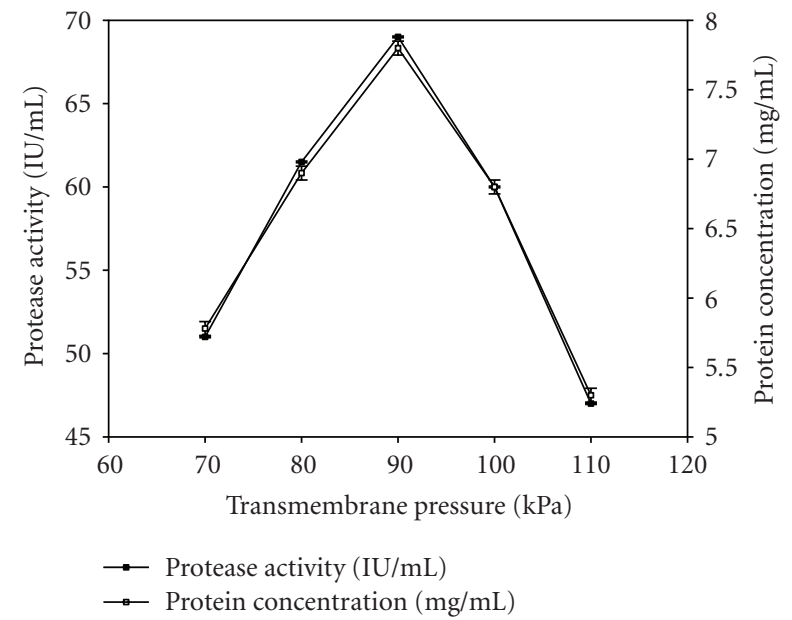

Figure 1: Protease activity and protein concentration in the retentate at different transmembrane pressures.

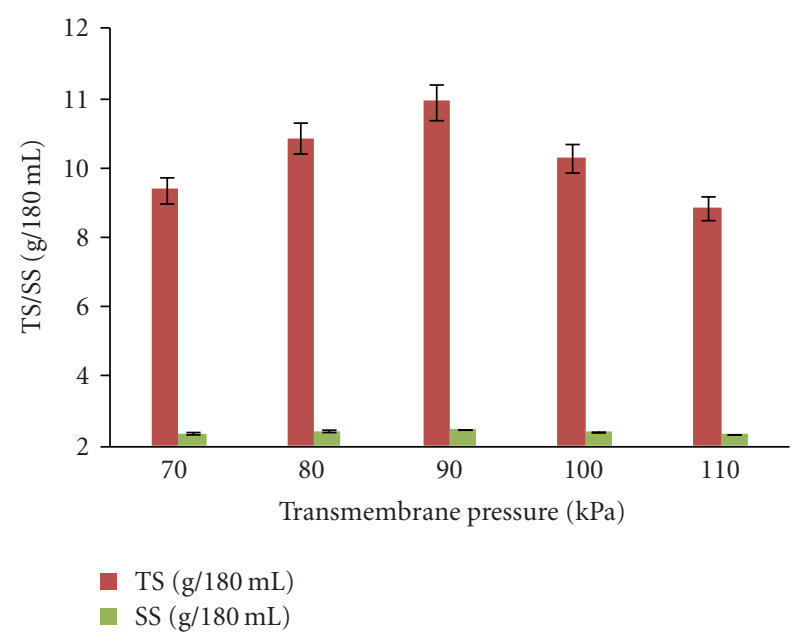

FIGURE 2: Total solids (TS) and suspended solids (SS) concentration in the retentate at different transmembrane pressures.

assay conditions. The control was maintained without any detergent and enzyme activity was taken as $100 \%$.

2.8. Application of Alkaline Protease in Removing Blood Stains. Application of protease enzyme ( $2 \mathrm{~mL}$ recovered enzyme) as detergent additive in removing blood stains was studied on white square cotton cloth pieces measuring $4 \times 4 \mathrm{~cm}$ prestained with goat blood according to the method of
Adinarayana [17]. The stained cloths were air dried for $1 \mathrm{~h}$ to fix the stain. Each of these stained cloth pieces were taken in separate flasks and the following setups were prepared.

(1) Flask with distilled water $(100 \mathrm{~mL})+$ stained cloth.

(2) Flask with distilled water $(100 \mathrm{~mL})+$ stained cloth $+1 \mathrm{~mL}$ of respective detergent solution at $7 \mathrm{mg} / \mathrm{mL}$.

(3) Flask with distilled water $(100 \mathrm{~mL})+$ stained cloth $+1 \mathrm{~mL}$ of respective detergent solution $(7 \mathrm{mg} / \mathrm{mL})$ $+2 \mathrm{~mL}$ of enzyme solution (114 IU/mL).

The above flasks were incubated at $60^{\circ} \mathrm{C}$ for $15 \mathrm{~min}$. After incubation, cloth pieces were taken out, rinsed with water, and dried. Visual examination of various pieces exhibited the effect of enzyme in removal of stains. Untreated cloth pieces stained with blood were taken as control.

\section{Results and Discussion}

\subsection{Optimization of Parameters of UF}

3.1.1. Transmembrane Pressure (TMP). The TMP was given by [6]

$$
\mathrm{TMP}=\left[\frac{P_{\text {feed }}+P_{\text {net }}}{2}\right]-P_{\text {perm }}
$$

TMP is function of the pressure of the retentate and that of feed which is adjusted by pressure gauge in order to get different values of TMP. Different TMP values were tested range from $70 \mathrm{kPa}$ to $110 \mathrm{kPa}$ to get the optimum TMP value. Profiles of protease activity, soluble protein, total solids, and suspended solids in the retentate were presented in Figures 1 and 2, respectively. All of these values (protease activity, soluble protein, total solids, and suspended solids) were not detectable in permeate as the size of alkaline proteases were in range between $20-30 \mathrm{kDa}$ [11] which is larger than MWCO of $10 \mathrm{kDa}$ membrane. Adjalle et al. [6] reported negligible values of viable spores, total cells and turbidity in the different ultrafiltrated permeates of different fermented broths as sizes of spores and cells of $B$. thuriegensis $(25 \mathrm{kDa}$ and $30 \mathrm{kDa})$ during recovery of biopesticide are greater than MWCO of $5 \mathrm{kDa}$ membrane. Higher protease activity $(69 \mathrm{IU} / \mathrm{mL})$, soluble protein $(7.8 \mathrm{mg} / \mathrm{mL})$, total solids $(12 \mathrm{~g} / \mathrm{L})$, and suspended solids $(2.7 \mathrm{~g} / \mathrm{L})$ were obtained with $90 \mathrm{kPa}$ among all other TMP values used. All tested components were concentrated to 4.5 times in the retentate than their initial values (supernatant) (Table 3 ). The fact that the protease activity was not detectable in all permeates. 
So, $83 \%$ of protease activity was recovered in retentate with TMP of $90 \mathrm{kPa}$. Therefore, it is apparent that some of the protease was lost as a deposit on the membrane and/or in the tubes. TMP values higher or lower than $90 \mathrm{kPa}$ were resulted in lower values of protease activity, soluble protein, total solids, and suspended solids. This may be because when TMP is lower than optimum value, feed pressure may not be sufficient to pass the solution through the membrane effectively and loss of components might have occurred in tubes or on the membrane surface. When TMP was high, this high pressure had cause foaming in ultrafiltration membrane which was retained in tubes and eventually components loss on membrane and in tubes might have occurred in the form of foam as they cannot be retained either in the permeate or in the retentate. Flow of the solute across the membranes certainly leads to clogging of some of the pores, creating additional surfaces for adsorption and caking. As gentle conditions are required for the recovery of the intact proteins, it would be difficult to remove/recover these proteins. Various mechanisms could generate these losses through the ultrafiltration membrane, as some of the sample components are close to the MWCO of the membranes. Primary cause of the loss of the enzyme protein through the membrane is the pore size distribution, while shear forces could also contribute by producing smaller fragments [25]. According to ultrafiltration principle, minimum flow of permeate will result in minimum loss or no loss of solute (protease in the present context) in the permeate and will give high concentration in retentate. Minimal flow of the permeate can be obtained with an optimal value of the TMP [6]. Adjalle et al. [26] recorded TMPs of $90 \mathrm{kPa}$ and $100 \mathrm{kPa}$ were optimum values for entomotoxicity recovery from starch industry wastewater and thermal hydrolyzed sludge medium, respectively. Other researcher reported that $20 \mathrm{kPa}$ was best for the separation of serine alkaline protease from neutral protease and amylase and $100 \mathrm{kPa}$ for the separation of serine alkaline protease from the organic and amino acids [3]. The optimum TMP is different for different cases and may be due to the rheological characteristics and other components present in the feed samples.

3.1.2. Feed Flux. Profiles of protease activity, soluble protein, total solids, and suspended solids versus different feed fluxes at TMP of $90 \mathrm{kPa}$ were presented in Figures 3 and 4 . Different feed flux values between $455 \mathrm{~L} / \mathrm{h} / \mathrm{m}^{2}$ and $2500 \mathrm{~L} / \mathrm{h} / \mathrm{m}^{2}$ were used by keeping the circulation of fluid at flow rate between $45.5 \mathrm{~L} / \mathrm{h}$ (lowest speed) and $250 \mathrm{~L} / \mathrm{h}$ (highest speed). During feed flux optimization, for each feed flux value, the retentate pressure was adjusted in order to maintain same TMP of $90 \mathrm{kPa}$. The feed flux of $714 \mathrm{~L} / \mathrm{h} / \mathrm{m}^{2}$ gave highest values of protease activity, soluble protein, total solids, and suspended solids in the retentate among all feed fluxes used. All of these values were not detectable in all permeates as explained earlier. Protease activity, soluble protein, total solids, and suspended solids were concentrated to 4.5 times than their initial values (supernatant) (Table 3 ). $81 \%$ of the protease (in terms of activity) was recovered in the retentate at feed flux of $714 \mathrm{~L} / \mathrm{h} / \mathrm{m}^{2}$. No protease was detected in the permeate as

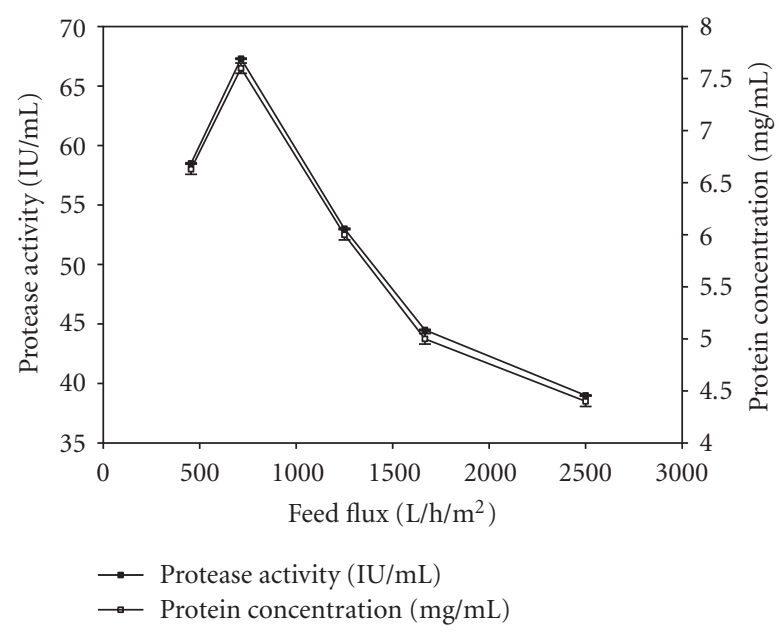

FIGURE 3: Protease activity and protein concentration in the retentate at different feed flux rates.

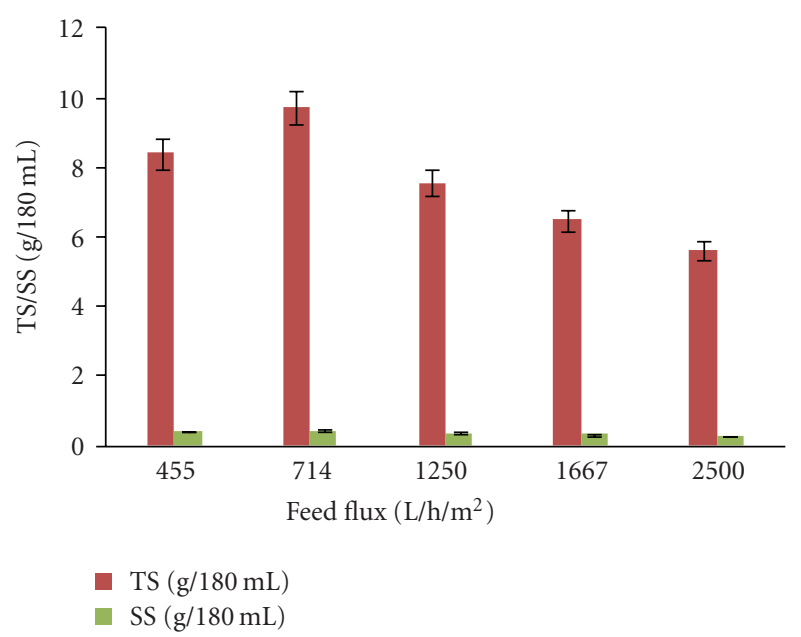

FIGURE 4: Total solids (TS) and suspended solids (SS) concentration in the retentate at different feed flux rates.

most of the protease was recovered in the retentate and some of the protease might get lost as deposit on the membrane. $\mathrm{Li}$ et al. [27] reported that purities of proteases were increased more than ten times at flow rate of $360 \mathrm{~L} / \mathrm{h}$ while separation of proteases from yellow fin tuna spleen by ultrafiltration, and Adjalle et al. [26] reported $550 \mathrm{~L} / \mathrm{h} / \mathrm{m}^{2}$ and $720 \mathrm{~L} / \mathrm{h} / \mathrm{m}^{2}$ as optimal values for entomotoxic components (crystal protein, protease etc.) from starch industry wastewater and thermal hydrolyzed sludge medium, respectively. Protease activity, protein, total solids, and suspended solids concentrations were decreased with higher feed flux values (1250, 1667 and $2500 \mathrm{~L} / \mathrm{h} / \mathrm{m}^{2}$ ). This decrease with high feed flux values due to the fact that high flux can degrade product quality due to the generation of turbulence effect [28]. Moreover, higher turbulence can cause severe foam in the retentate stream which will create a vacuum and further decrease the permeate flux below the optimum value; hence, administer the overall performance of the ultrafiltration system [6]. The vibration in the filtration unit due to the higher feed flux can 


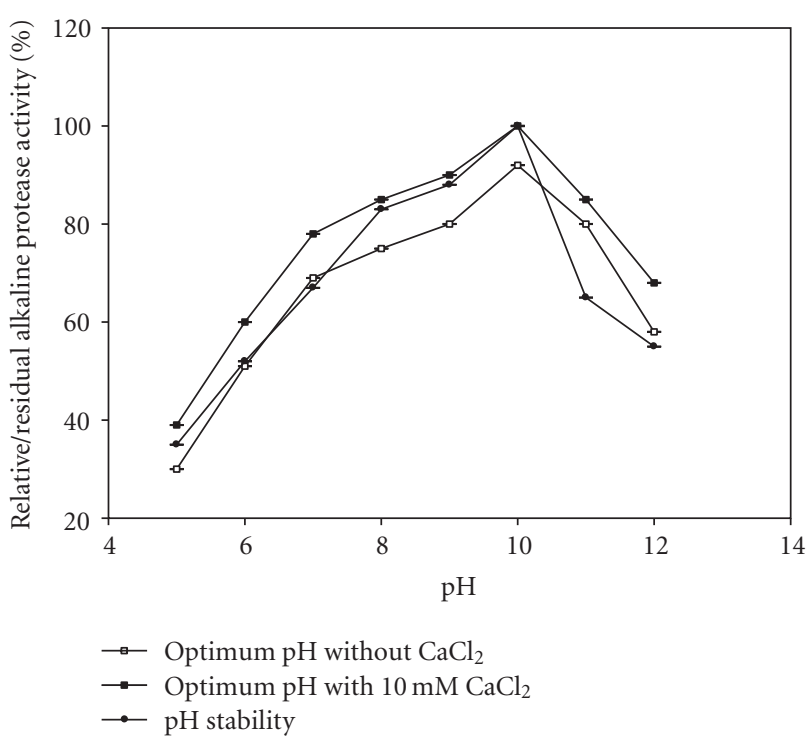

FIGURE 5: Effect of $\mathrm{pH}$ on the activity and stability of alkaline protease in the absence and presence of $10 \mathrm{mM} \mathrm{CaCl}_{2}$.

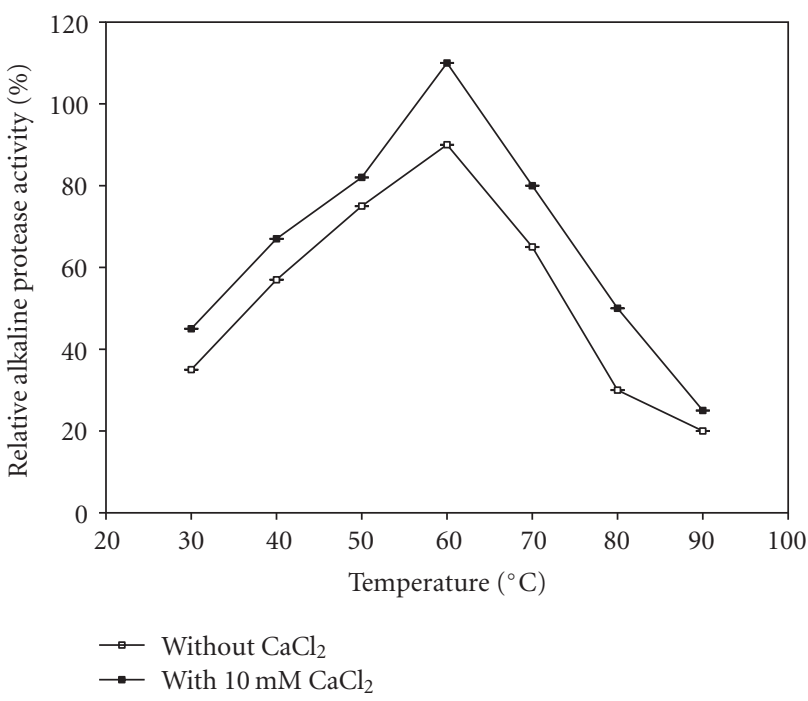

FIGURE 6: Effect of temperature profiles on activity of enzyme in the absence and presence of $10 \mathrm{mM} \mathrm{CaCl}_{2}$.

cause foaming due to proteins (enzymes and other soluble proteins) present in the medium [29].

\subsection{Characterization of Partially Purified Enzyme}

3.2.1. Effect of pH on Enzyme Activity and Stability of Protease. $\mathrm{pH}$ is a determining factor in the expression of an enzyme activity as it alters the ionization state of the amino acid or ionization of substrate. The ionization state of enzymes is undoubtedly one of the most crucial parameters that control substrate binding, catalytic enzyme action, and three-dimensional structure of enzyme molecule. Effect of $\mathrm{pH}$ on enzyme activity (permeate of $100 \mathrm{kDa}$ ) and stability in the presence and absence of $10 \mathrm{~mm} \mathrm{CaCl}_{2}$ are presented in Figure 5. The partially purified protease was found to be typical alkaline protease displaying its maximum activity at alkaline $\mathrm{pH} 10$ as optimum, and it decreased sharply with increase in $\mathrm{pH}$. The active site of the enzyme is mainly composed of ionic groups that must be in proper ionic form to maintain the conformation of the active site of enzyme for substrate binding or reaction catalysis as conformation is sensitive to changes in the environment (like $\mathrm{pH}$ change) [30]. The optimum $\mathrm{pH}$ obtained for this enzyme was higher than other reports showing $\mathrm{pH}$ optimum of 8 for protease from Haloferax lucentensis VKMM 007 [31] and $\mathrm{pH}$ optimum of 9 for protease from B. stearothermophilus [15]. However, the findings of optimum $\mathrm{pH}$ for this enzyme was in accordance with other findings who also reported $\mathrm{pH}$ of 10-10.5 as optimum for proteases from B. subtilis PE11, B. cereus and Vibrio metschnikovi $[17,32,33]$. Protease stability of concentrated protease in presence and absence of $10 \mathrm{~mm} \mathrm{CaCl} 2$ is shown in Figure 5 . When protease was preincubated with various buffers over broad $\mathrm{pH}$ values ( $\mathrm{pH} 5-12)$ for $2 \mathrm{~h}$ and then measured for residual activity, the protease showed highest stability over a broad range of pH 8 to 10 . The enzyme stability declined to nearly $55 \%$ when $\mathrm{pH}$ values were higher than 10 . The most important feature of the present protease is alkaline enzyme, as it was stable in the alkaline $\mathrm{pH}$ up to 11 , and it can be used as additive in detergent industry. Usually, commercially important proteases from microorganisms have highest activity in the alkaline $\mathrm{pH}$ range of $8-12[40,45]$.

3.2.2. Effect of Temperature on Activity and Stability of Protease. Temperature profiles on enzyme activity in the presence and absence of $10 \mathrm{~mm} \mathrm{CaCl} 2$ are shown in Figure 6 . In the present study, temperatures ranging from $30^{\circ} \mathrm{C}-90^{\circ} \mathrm{C}$ were studied in the absence and presence of $10 \mathrm{~mm} \mathrm{CaCl}_{2}$. Optimum temperature for this enzyme was found to be $60^{\circ} \mathrm{C}$. The enzyme activity was declined gradually when temperatures were higher than $60^{\circ} \mathrm{C}$. Similar results were reported by other researchers where optimum temperature of $60^{\circ} \mathrm{C}$ was recorded for proteases from Haloferax lucentensis VKMM 007 and B. mojavensis $[31,34]$. In contrary to these results, an optimum temperature of $75^{\circ} \mathrm{C}$ was reported for protease of B. laterosporus-AK1 [35].

Temperature profile on enzyme stability was presented in Figure 7. Thermal stability of the enzyme was studied at different temperatures of $60^{\circ} \mathrm{C}, 70^{\circ} \mathrm{C}, 75^{\circ} \mathrm{C}$, and $80^{\circ} \mathrm{C}$ for different time periods ( 30 to $180 \mathrm{~min}$ ) in the presence of $10 \mathrm{~mm} \mathrm{CaCl}$. The enzyme was $97 \%$ stable at $60^{\circ} \mathrm{C}$ even after $180 \mathrm{~min}$ of incubation and at $70^{\circ} \mathrm{C}$ up to $41 \%$ stable after $180 \mathrm{~min}$ incubation. But, the enzyme was completely unstable at $75^{\circ} \mathrm{C}$ after $90 \mathrm{~min}$ of incubation and at $80^{\circ} \mathrm{C}$ after $60 \mathrm{~min}$ of incubation due to thermal inactivation. The main course of action found to be involved in the thermal denaturation of enzyme was due to the dissociation of ionic groups from the holoenzyme and modification or degradation of prosthetic group [30]. Beg and Gupta [34] reported $86 \%$ of stability at $60^{\circ} \mathrm{C}$ for protease from $B$. mojavensis and Shanmughapriya et al. [36] reported enzyme stability only up to $40^{\circ} \mathrm{C}$ for protease from marine Roseobacter sp. MMD040. 


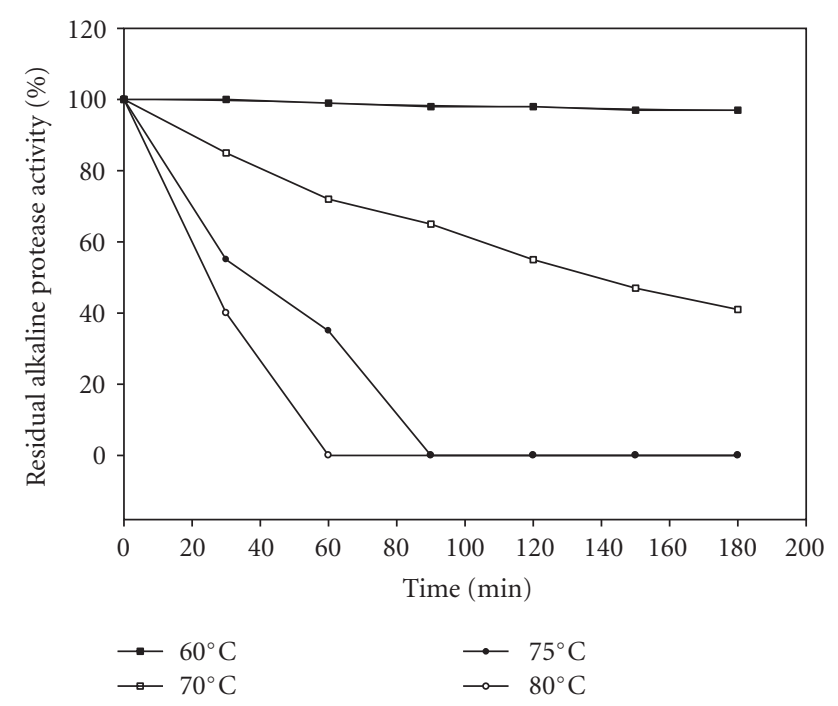

FIGURE 7: Effect of temperature on stability of alkaline protease enzyme (ultrafiltrated samples) in the presence of $10 \mathrm{mM} \mathrm{CaCl}_{2}$.

The present enzyme from B. licheniformis ATCC 21424 is thermostable as thermostable enzymes are stable and active at temperatures which are even higher than the optimum temperatures for the growth of the microorganisms [37]. So, this enzyme can be very well applied as additive in detergent industries, as it can withstand harsh washing conditions of operation because of its stability at high temperatures.

\subsubsection{Effect of Enzyme Inhibitor and Chelator on Protease} Activity. Inhibition studies primarily give an insight of the nature of an enzyme, its cofactor requirements and the nature of the active center [38]. The effect of different inhibitors and chelator on enzyme activity was investigated and results were presented in Table 4. Among all the inhibitors tested ( $5 \mathrm{~mm}$ concentration), PMSF inhibited the protease activity completely and DFP was able to inhibit protease activity up to $90 \%$. In this context, PMSF sulphonates the vital serine residue in the active site of the protease and has been reported to inactivate the enzyme activity completely [39]. Hence, this protease can be classified as serine protease. Our results are in accordance with other studies, where protease was completely inhibited by PMSF $[17,31]$. EDTA and Diothiotheritol did not inhibit enzyme activity at all, but $p \mathrm{CMB}$ and $\beta$-ME inhibited the enzyme activity slightly.

3.2.4. Effect of Various Metal Ions on Enzyme Activity. Effect of various metal ions with $5 \mathrm{~mm}$ concentration on the enzyme activity was tested and results were presented in Table 5. Some metal ions $\left(\mathrm{Ca}^{2+}\right.$ and $\left.\mathrm{Mn}^{2+}\right)$ had enhancing effect on the enzyme activity, while other ions $\left(\mathrm{Mg}^{2+}, \mathrm{Zn}^{2+}\right.$, $\mathrm{Cu}^{2+}, \mathrm{Co}^{2+}$, and $\mathrm{Na}^{+}$) had no effect or slight inhibitory effect on the enzyme activity. Some of the metal ions such as $\mathrm{Ca}^{2+}$, $\mathrm{Mn}^{2+}$, and $\mathrm{Mg}^{2+}$ increased and stabilized protease enzyme activity; this may be due to the activation by the metal ions. Results show that these metal ions protected the enzyme
TABLE 4: Effect of enzyme inhibitor and chelator on protease activity.

\begin{tabular}{lc}
\hline Inhibitor/chelator $(5 \mathrm{mM})$ & $\begin{array}{c}\text { Relative enzyme } \\
\text { activity }(\%)\end{array}$ \\
\hline Control & 100 \\
$\beta$-Mercaptoethanol & $78 \pm 3.8$ \\
$p$-chloromercuric benzoate ( $p$-CMB) & $91 \pm 4.3$ \\
Phenylmethyl sulphonyl fluoride (PMSF) & 0 \\
Diisopropyl fluorophosphate (DFP) & $10 \pm 0.5$ \\
Iodoacetate & $96 \pm 4.4$ \\
Ethelene diamine tetra acetic acid (EDTA) & $110 \pm 5.6$ \\
Dithiotheritol & $100 \pm 4.8$ \\
\hline
\end{tabular}

TABLE 5: Effect of metal ions on alkaline protease activity.

\begin{tabular}{lc}
\hline Metal ions $(5 \mathrm{~mm})$ & $\begin{array}{c}\text { Residual alkaline } \\
\text { protease activity }(\%)\end{array}$ \\
\hline Control & 100 \\
$\mathrm{Ca}^{2+}$ & $125 \pm 6.1$ \\
$\mathrm{~K}^{+}$ & $6 \pm 0.26$ \\
$\mathrm{Fe}^{2+}$ & $66 \pm 3.1$ \\
$\mathrm{Zn}^{2+}$ & $98 \pm 4.7$ \\
$\mathrm{Hg}^{2+}$ & $23 \pm 1.1$ \\
$\mathrm{Mg}^{2+}$ & $99 \pm 4.8$ \\
$\mathrm{Mn}^{2+}$ & $114 \pm 5.5$ \\
$\mathrm{Cu}^{2+}$ & $95 \pm 4.6$ \\
$\mathrm{Co}^{2+}$ & $91 \pm 4.4$ \\
$\mathrm{Na}^{+}$ & $96 \pm 4.7$ \\
\hline
\end{tabular}

TABLE 6: Activity of alkaline protease against different natural proteins.

\begin{tabular}{lc}
\hline Protein $(2 \mathrm{mg} / \mathrm{mL})$ & Relative enzyme activity $(\%)$ \\
\hline Casein & 100 \\
Gelatin & $3 \pm 0.14$ \\
BSA & $54 \pm 2.6$ \\
Egg albumin & $35 \pm 1.7$ \\
\hline
\end{tabular}

activity against thermal inactivation and played a vital role in maintaining active conformation of the enzyme at higher temperatures [40]. Metal ions $\mathrm{Hg}^{2+}$ and $\mathrm{K}^{+}$had showed maximum inhibition on the enzyme activity, while $\mathrm{Fe}^{2+}$ inhibited the enzyme activity up to $34 \%$. The inhibitory effect of heavy metal ions is well reported in the previous reports and it is well known that ions of mercury react with protein thiol groups and also with histidine and tryptophan residues. Moreover, the disulfide bonds were found to be hydrolytically degraded by the action of mercury [40].

3.2.5. Hydrolysis of Protein Substrates. Effect of some native proteins as substrates on enzyme was studied and results were presented in Table 6. Among all substrates, protease showed higher hydrolytic activity (100\%) against casein and 
TABLE 7: Compatibility of alkaline protease activity from B. licheniformis with commercial detergents.

\begin{tabular}{|c|c|c|c|c|c|c|}
\hline \multicolumn{7}{|c|}{ Relative enzyme activity (\%) } \\
\hline Time $(\mathrm{h})$ & Control & Sunlight & La Parisienne & Merit selection & Arctic power & Bio-vert \\
\hline 0.0 & 100 & 100 & 100 & 100 & 100 & 100 \\
\hline 0.5 & 97 & 95 & 90 & 89 & 91 & 88 \\
\hline 1.0 & 93 & 91 & 82 & 80 & 83 & 81 \\
\hline 1.5 & 90 & 88 & 71 & 69 & 72 & 70 \\
\hline 2.0 & 84 & 81 & 65 & 61 & 64 & 64 \\
\hline 2.5 & 80 & 75 & 57 & 54 & 60 & 59 \\
\hline 3.0 & 74 & 62 & 52 & 48 & 55 & 50 \\
\hline
\end{tabular}

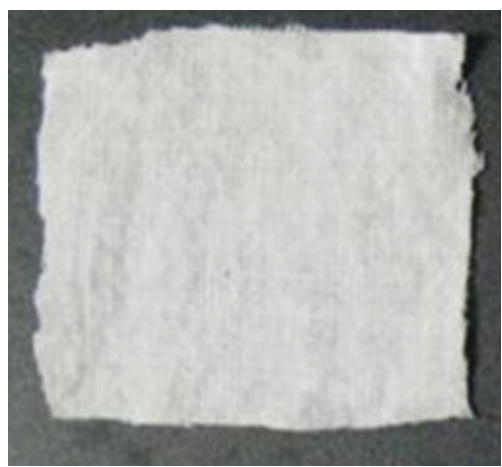

(a)

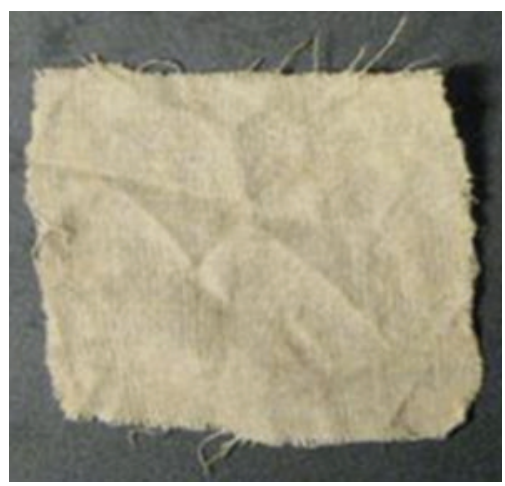

(d)

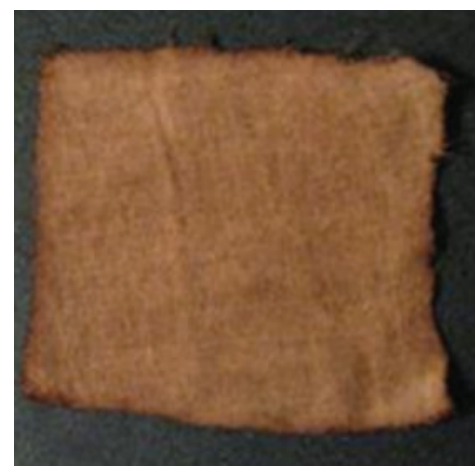

(b)

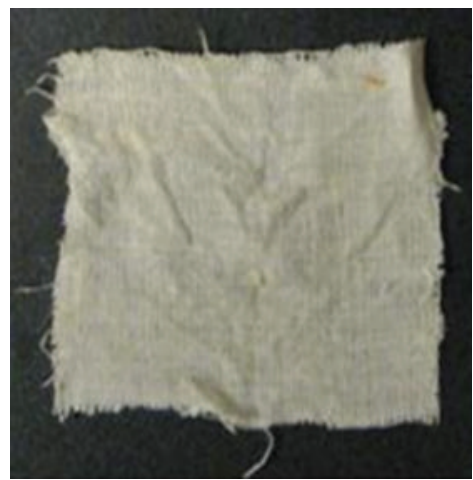

(e)

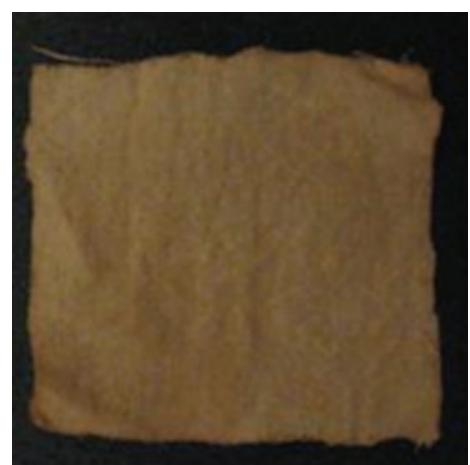

(c)

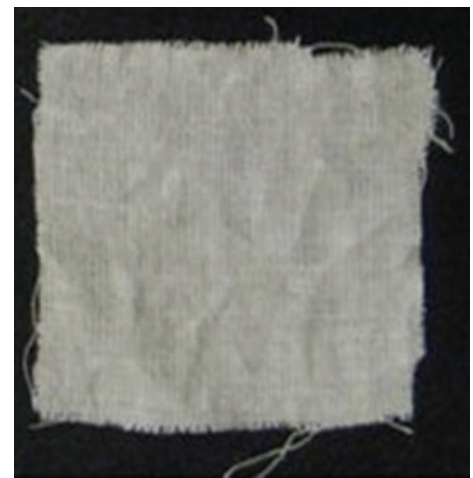

(f)

FIGURE 8: Washing test of alkaline protease from B. licheniformis ATCC 21424 in presence of detergent (Sunlight). (a) positive control, (b) negative control, (c) with distilled water, (d) with Enzyme alone, (e) with detergent alone, and (f) with enzyme + detergent.

the enzyme showed moderate hydrolysis of both BSA (54\%) and egg albumin (35\%). Previous researchers also reported that alkaline proteases showed higher activity with casein $[40,41]$. But protease did not show any hydrolysis with gelatin. This may be due to the enzymatic cleavage of peptide bonds of gelatin is difficult because of its rigid structure and the restricted enzyme substrate interaction on the surface of gelatin [42]. Different protein substrates contain different amino acid contents and the assay procedure used in this study by detection of tryptophan and tyrosine. So, lesser hydrolysis of other substrates compared to casein may be due to less quantity of detectable amino acid in hydrolyzed product. For example, gelatin has no tryptophan residue.
3.2.6. Effect of Detergents on Stability of Protease Activity. Protease used for detergent additive is expected to be stable in the presence of various commercial detergents. The protease from B. licheniformis ATCC 21424 was tested for its stability in the presence of different commercial detergents. Excellent stability and compatibility was observed with protease in presence of wide range of commercial detergents (Sunlight, Arctic Power, la Parisienne, Merit Selection and Bio-vert) at $60^{\circ} \mathrm{C}$ in the presence of $\mathrm{CaCl}_{2}$ as stabilizer. The protease showed good stability and compatibility in the presence of Sunlight followed by Arctic Power (Table 7). Significant activity (nearly 50\%) was retained by the enzyme with most of the detergents tested even after $3 \mathrm{~h}$ incubation at $60^{\circ} \mathrm{C}$. Protease from Streptomyces fungicidicus MML1614 
showed compatibility with various commercial detergents and significant activity was retained only up to $90 \mathrm{~min}$ of incubation [15] and protease from Conidiobolus coronatus showed compatibility with different commercial detergents at $50^{\circ} \mathrm{C}$ with $25 \mathrm{~mm} \mathrm{CaCl}_{2}$ concentration, only $16 \%$ activity in Revel, $11.4 \%$ activity in Aerial, and $6.6 \%$ activity in Wheel after incubation [43]. B. licheniformis RP1 protease was stable with detergents at $40^{\circ} \mathrm{C}-50^{\circ} \mathrm{C}$ only up to $60 \mathrm{~min}$ [44]. In comparison with these results, our protease from $B$. licheniformis ATCC 21424 was appreciably more stable in the presence of commercial detergents.

3.3. Washing Test With B. licheniformis Protease in Removing Blood Strains. Protease produced by B. licheniformis ATCC 21424 was considerably stable in a wide range of $\mathrm{pH}$ and temperature and even showed good compatibility with commercial detergents. So, it was tested as an additive with detergent, to check washing performance of the detergent with this additive protease. When the protease preparation was combined with commercial detergent (Sunlight), washing performance of the detergent was enhanced in removing the blood stain from white cotton cloth (Figure 8). Similarly, proteases of B. subtilis [17] and Streptomyces fungicidicus [15] efficiently removed blood stains from white cotton cloth pieces when combined with commercial detergents. Even though alkaline proteases from Bacillus spp. are stable at high temperature and alkaline $\mathrm{pH}$, most of them are incompatible with detergent matrices $[45,46]$. Concentrated enzyme from supernatant of sludge fermented by $B$. licheniformis ATCC 21424 showed higher tolerance with detergent and efficiently removed the blood stain.

\section{Conclusion}

In this study, enzyme was concentrated and characterized to apply as additive in detergents as detergent industry needs concentrated enzyme in order to have higher efficiency. The recovery of alkaline protease using ultrafiltration process with an optimum transmembrane pressure of $90 \mathrm{kPa}$ and feed flux of $714 \mathrm{~L} / \mathrm{h} / \mathrm{m}^{2}$ showed a recovery of $83 \%$ of the protease activity. The protease from $B$. licheniformis ATCC 21424 is thermostable and alkali-tolerant serine alkaline protease, as it is stable at alkaline $\mathrm{pH}$ and high temperature. Recovered alkaline thermostable protease by ultrafiltration can be exploited in detergent industry as an additive, because it showed excellent stability at wide range of temperature and compatibility with commercial detergents. More importantly, the supplementation of the enzyme preparation to detergent could remarkably remove the blood stains of white cotton cloth.

\section{Acknowledgments}

The authors are sincerely thankful to Natural Sciences and Engineering Research Council of Canada (Grants nos. A4984, Canada Research Chair) for financial support. The views and opinions expressed in this paper are those of authors and should not be construed as opinions of the U.S. Environmental Protection Agency.

\section{References}

[1] Z. Cui, "Protein separation using ultrafiltration-an example of multi-scale complex systems," China Particuology, vol. 3, no. 6, pp. 343-348, 2005.

[2] A. Moure, H. Dominguez, and J. C. Parajo, "Antioxidant properties of ultrafiltration-recovered soy protein fractions from industrial effluents and their hydrolysates," Process Biochemistry, vol. 41, no. 2, pp. 447-456, 2006.

[3] S. Takac, S. Elmas, P. Calik, and T. H. Özdamar, "Separation of the protease enzymes of $B$. licheniformis from the fermentation medium by crossflow ultrafiltration," Journal of Chemical Technology and Biotechnology, vol. 75, no. 6, pp. 491-499, 2000.

[4] Y. Tzeng, Y. Tsun, and Y. Chang, "Recovery of thuringiensin with cetylpyridinium chloride using Micellar-Enhanced ultrafiltration process," Biotechnology Progress, vol. 15, no. 3, pp. 580-586, 1999.

[5] Y. Li, A. Shahbazi, and C. T. Kadzere, "Separation of cells and proteins from fermentation broth using ultrafiltration," Journal of Food Engineering, vol. 75, no. 4, pp. 574-580, 2006.

[6] K. D. Adjalle, S. K. Brar, M. Verma, R. D. Tyagi, J. R. Valero, and R. Y. Surampalli, "Ultrafiltration recovery of entomotoxicity from supernatant of $B$. thuringiensis fermented wastewater and wastewater sludge," Process Biochemistry, vol. 42, no. 9, pp. 1302-1311, 2007.

[7] J. Bohdziewicz and M. Bodzek, "Ultrafiltration preparation of pectinolytic enzymes from citric acid fermentation broth," Process Biochemistry, vol. 29, no. 2, pp. 99-107, 1994.

[8] J. Bohdziewicz, "Ultrafiltration of technical amylolytic enzymes," Process Biochemistry, vol. 31, no. 2, pp. 185-191, 1996.

[9] T. G. O. Sullivan, A. C. Epstein, S. R. Korchin, and N. C. Beaton, "Applications of ultrafiltration in biotechnology," Chemical Engineering Progress, vol. 80, no. 1, pp. 68-75, 1984.

[10] P. Caizares, Á. Pérez, and R. Camarillo, "Recovery of heavy metals by means of ultrafiltration with water-soluble polymers: calculation of design parameters," Desalination, vol. 144, no. 1-3, pp. 279-285, 2002.

[11] C. G. Kumar and T. Hiroshi, "Microbial alkaline proteases: from a bioindustrial viewpoint," Biotechnology Advances, vol. 17, no. 7, pp. 561-594, 1999.

[12] C. Christy and S. Vermant, "The state-of-the-art of filtration in recovery processes for biopharmaceutical production," Desalination, vol. 147, no. 1-3, pp. 1-4, 2002.

[13] E. Darnon, E. Morin, G. M. Bellville, and M. P. Rios, "Ultrafiltration within downstream processing: some process design consideration," Chemical Engineering Progress, vol. 42, pp. 299-309, 2003.

[14] R. Ghosh, "Novel cascade ultrafiltration configuration for continuous, high-resolution protein-protein fractionation: a simulation study," Journal of Membrane Science, vol. 226, no. 1-2, pp. 85-99, 2003.

[15] S. Ramesh, M. Rajesh, and N. Mathivanan, "Characterization of a thermostable alkaline protease produced by marine Streptomyces fungicides MML1614," Bioprocess and Biosysems Engineering, vol. 32, pp. 791-800, 2009.

[16] Q. K. Beg, V. Sahai, and R. Gupta, "Statistical media optimization and alkaline protease production from B. mojavensis in 
a bioreactor," Process Biochemistry, vol. 39, no. 2, pp. 203-209, 2003.

[17] K. Adinarayana, P. Ellaiah, and D. Prasad, "Purification and partial characterization of thermostable serine alkaline protease from a newly isolated B. subtilis PE-11," AAPS PharmSciTech, vol. 4, no. 4, pp. 440-448, 2003.

[18] B. Jaouadi, S. Ellouz-Chaabouni, Ali M. B. et al., "Excellent laundry detergent compatibility and high dehairing ability of the B. pumilus CBS alkaline proteinase (SAPB)," Biotechnology and Bioprocess Engineering, vol. 14, no. 4, pp. 503-512, 2009.

[19] J. Bezawada, S. Yan, R. D. Tyagi, and R. Y. Surampalli, "Comparision of protease activities in different Bacillus licheniformis strains using wastewater sludge and synthetic soy medium as raw material," Environmental Technology, vol. 31, no. 1, pp. 6372, 2010.

[20] J. Bezawada, S. Yan, P. Rojan, R. D. Tyagi, and R. Y. Surampalli, "Augmentation of protease production by supplementing carbon and nitrogen sources to wastewater sludge medium," Journal of Residual Science and Technology, vol. 7, no. 3, pp. 161-172, 2010.

[21] APHA, AWWA, WPCF, Standard Methods for Examination of Water and Wastewaters, American Public Health Association, Washington, DC, USA, 20th edition, 1998.

[22] S. K. Brar, M. Verma, R. D. Tyagi, J. R. Valéro, and R. Y. Surampalli, "Sludge based B. thuringiensis biopesticides: viscosity impacts," Water Research, vol. 39, no. 13, pp. 3001-3011, 2005.

[23] M. M. Braford, "A rapid and sensitive method for quantification of microgram quantities of protein utilizing the principle of protein-dye binding," Analytical Biochemistry, vol. 72, pp. 248-254, 1976.

[24] M. Kunitz, "Crystalline Soybean trypsin inhibitor," Journal of General Physiology, vol. 30, pp. 291-310, 1947.

[25] M. J. Powell and A. T. Timperman, "Quantitative analysis of protein recovery from dilute, large volume samples by tangential flow ultrafiltration," Journal of Membrane Science, vol. 252, no. 1-2, pp. 227-236, 2005.

[26] K. D. Adjalle, R. D. Tyagi, S. K. Brar, J. R. Valero, and R. Y. Surampalli, "Recovery of entomotoxicity components from Bacillus thuringiensis fermented wastewater and sludge: ultrafiltration scale-up approach," Separation and Purification Technology, vol. 69, no. 3, pp. 275-279, 2009.

[27] Z. Li, W. Youravong, and A. H-Kittikun, "Separation of proteases from yellowfin tuna spleen by ultrafiltration," Bioresource Technology, vol. 97, no. 18, pp. 2364-2370, 2006.

[28] Millipores, "Protein concentration and diafiltration by tangential flow filtration," Technical Brief, Millipore Publication, 2003, http://www.millipore.com/publications.nsf/docs/ tb032.

[29] M. S. Abdel-Ghani, "Cross-flow ultrafiltration of an aqueous polymer foam solution produced by gas sparging," Journal of Membrane Science, vol. 171, pp. 105-117, 2000.

[30] C. M. Ajila and U. J. S. Prasada Rao, "Purification and characterization of black gram (Vigna mungo) husk peroxidase," Journal of Molecular Catalysis B, vol. 60, no. 1-2, pp. 36-44, 2009.

[31] M. Manikandan, L. Pašić, and V. Kannan, "Purification and biological characterization of a halophilic thermostable protease from Haloferax lucentensis VKMM 007," World Journal of Microbiology and Biotechnology, vol. 25, no. 12, pp. 2247-2256, 2009.

[32] M. Prakash, R. M. Banik, and C. Koch-Brandt, "Purification and characterization of Bacillus cereus protease suitable for detergent industry," Applied Biochemistry and Biotechnology, vol. 127, no. 3, pp. 143-155, 2005.

[33] Y. T. Kwon, J. O. Kim, S. Y. Moon, H. H. Lee, and H. M. Rho, "Extracellular alkaline protases from alkalophilic Vibrio metschnikovii strain RH530," Biotechnology Letters, vol. 16, no. 4, pp. 413-418, 1994.

[34] Q. K. Beg and R. Gupta, "Purification and characterization of an oxidation-stable, thiol-dependent serine alkaline protease from Bacillus mojavensis," Enzyme and Microbial Technology, vol. 32, no. 2, pp. 294-304, 2003.

[35] M. Arulmani, K. Aparanjini, K. Vasanthi, P. Arumugam, M. Arivuchelvi, and P. T. Kalaichelvan, "Purification and partial characterization of serine protease from thermostable alkalophilic B. laterosporus-AK1," World Journal of Microbiology and Biotechnology, vol. 23, no. 4, pp. 475-481, 2006.

[36] S. Shanmughapriya, J. Krishnaveni, J. Selvin et al., "Optimization of extracellular thermotolerant alkaline protease produced by marine Roseobacter sp. (MMD040)," Bioprocess and Biosystems Engineering, vol. 31, no. 5, pp. 427-433, 2008.

[37] G. D. Haki and S. K. Rakshit, "Developments in industrially important thermostable enzymes: a review," Bioresource Technology, vol. 89, no. 1, pp. 17-34, 2003.

[38] D. S. Sigman and G. Mooser, "Chemical studies of enzyme active sites," Annual Review of Biochemistry, vol. 44, pp. 899931, 1975.

[39] A. M. Gold and D. Fahrney, "Sulfonyl fluorides as inhibitors of esterases: II. formation and reactions of phenylmethanesulfonyl $\alpha$-chymotrypsin," Biochemistry, vol. 3, no. 6, pp. 783$791,1964$.

[40] C. G. Kumar, M. P. Tiwari, and K. D. Jany, "Novel alkaline serine proteases from alkalophilic Bacillus sp.: purification and some properties," Process Biochemistry, vol. 34, no. 5, pp. 441449, 1999.

[41] N. Paliwal, S. P. Singh, and S. K. Garg, "Cation-induced thermal stability of an alkaline protease from a Bacillus sp," Bioresource Technology, vol. 50, no. 3, pp. 209-211, 1994.

[42] B. Bockle, B. Galunsky, and R. Muller, "Characterization of a keratinolytic serine proteinase from Streptomyces pactum DSM 40530," Applied and Environmental Microbiology, vol. 61, no. 10, pp. 3705-3710, 1995.

[43] S. H. Bhosale, M. B. Rao, V. V. Deshpande, and M. C. Srinivasan, "Thermostability of high-activity alkaline protease from Conidiobolus coronatus (NCL 86.8.20)," Enzyme and Microbial Technology, vol. 17, no. 2, pp. 136-139, 1995.

[44] A. Sellami-Kamoun, A. Haddar, N. El-Hadj Ali, B. GhorbelFrikha, S. Kanoun, and M. Nasri, "Stability of thermostable alkaline protease from Bacillus licheniformis RP1 in commercial solid laundry detergent formulations," Microbiological Research, vol. 163, no. 3, pp. 299-306, 2008.

[45] R. Gupta, Q. K. Beg, and P. Lorenz, "Bacterial alkaline proteases: molecular approaches and industrial applications," Applied Microbiology and Biotechnology, vol. 59, no. 1, pp. 1532, 2002.

[46] K. Saeki, K. Ozaki, T. Kobayashi, and S. Ito, "Detergent alkaline proteases: enzymatic properties, genes, and crystal structures," Journal of Bioscience and Bioengineering, vol. 103, no. 6, pp. 501-508, 2007. 

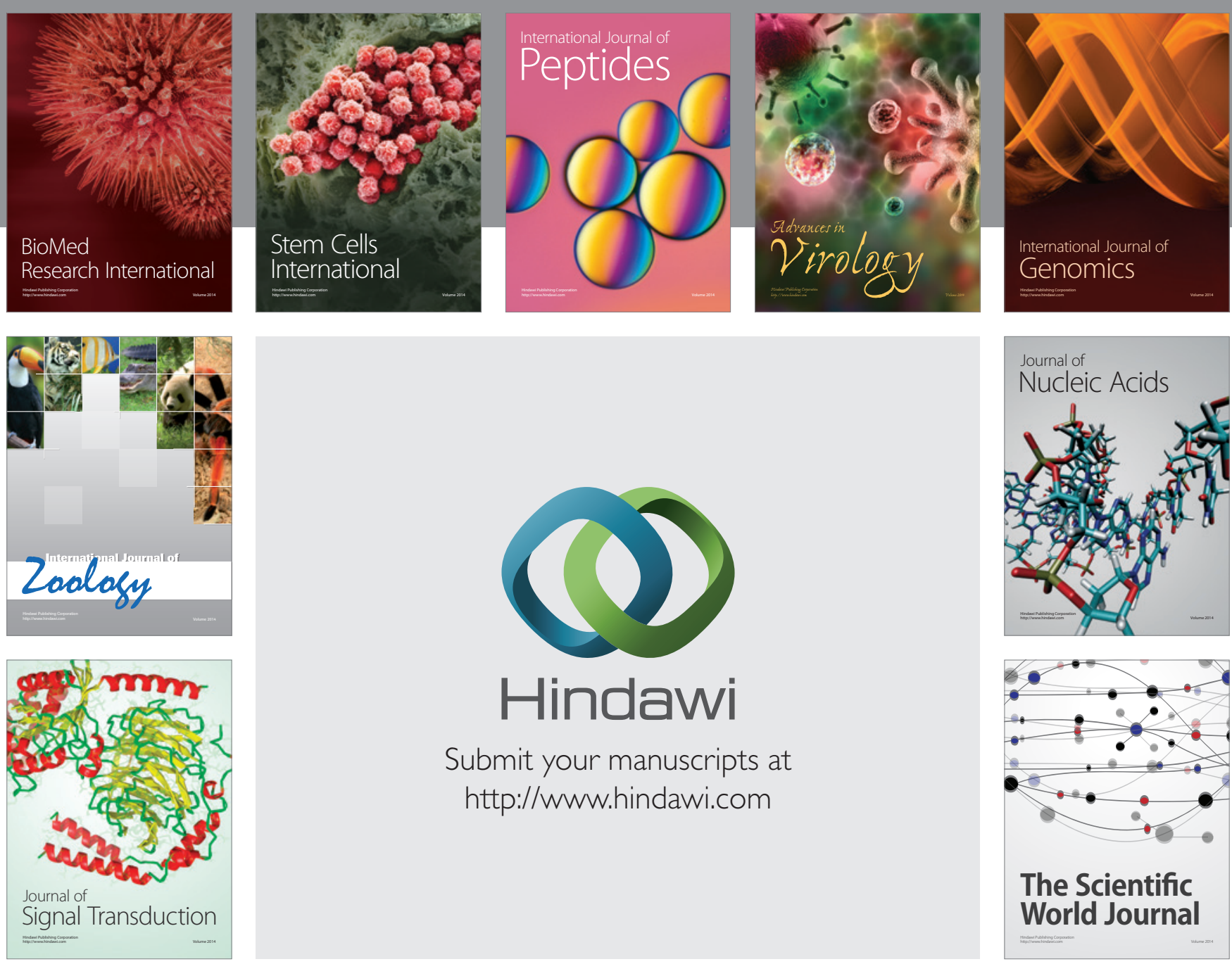

Submit your manuscripts at

http://www.hindawi.com
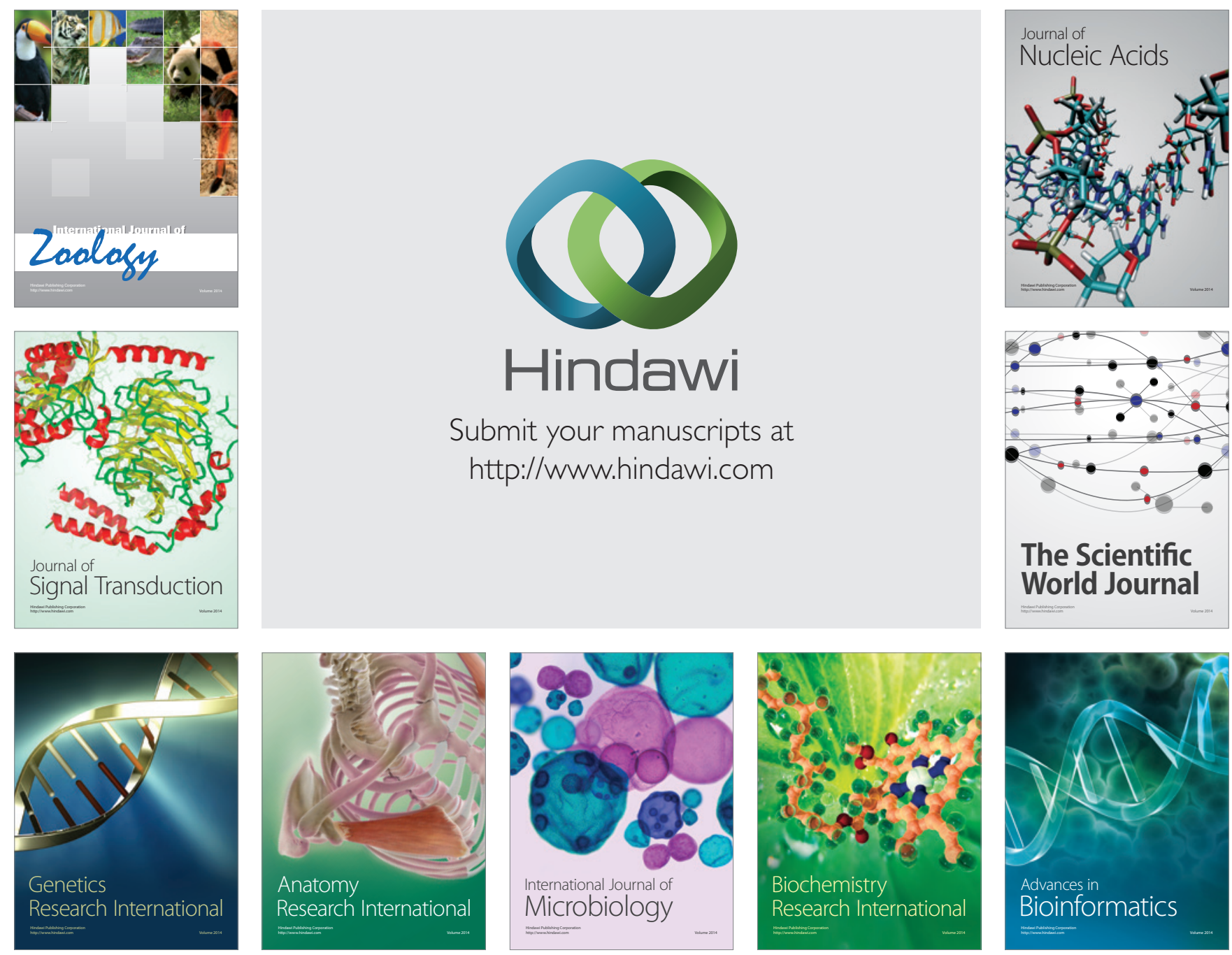

The Scientific World Journal
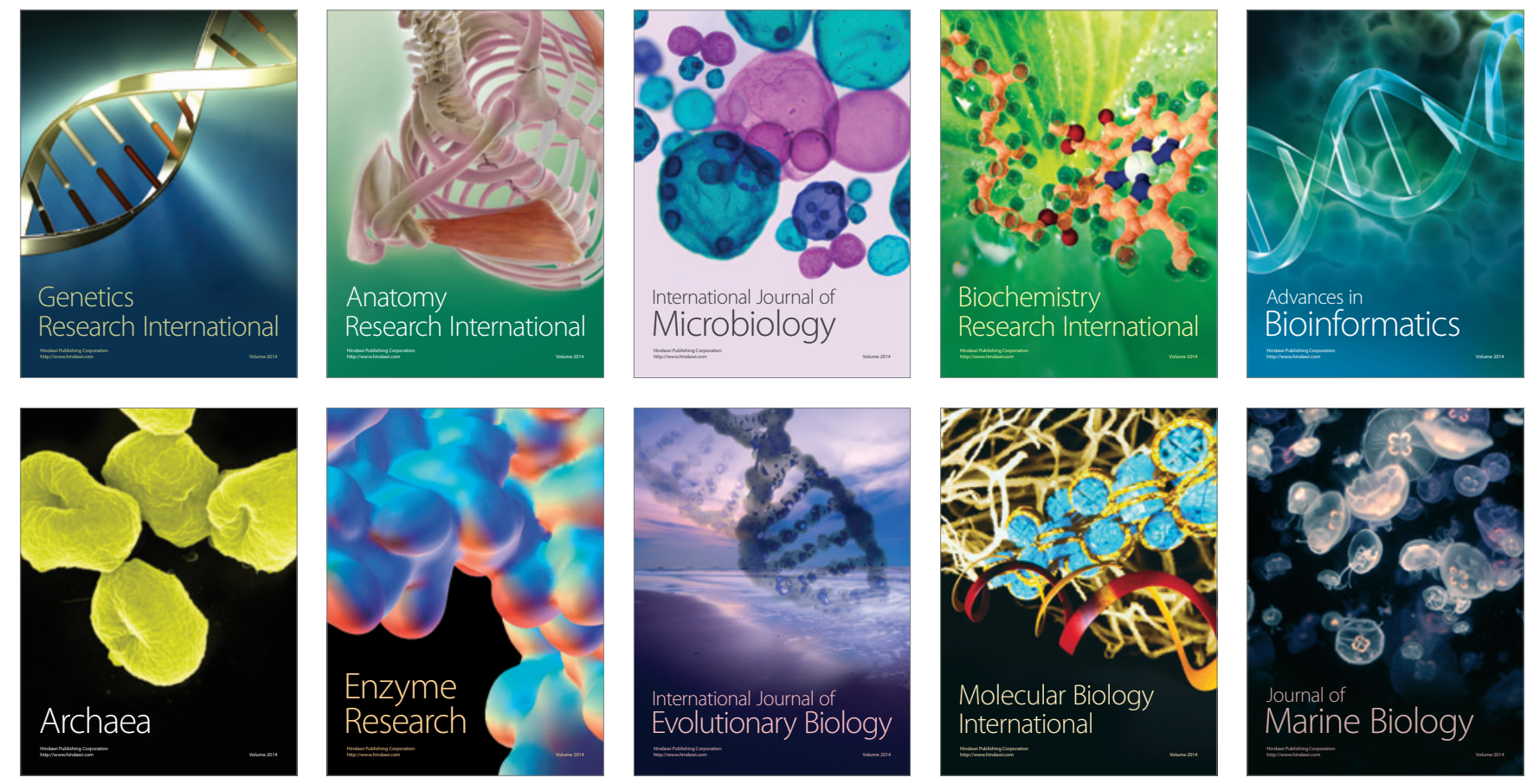